\title{
Antibiotic uptake by cultured Atlantic cod leucocytes and effect on intracellular Francisella noatunensis subsp. noatunensis replication
}

\author{
Marte Kaldestad $^{1}$, Gyri T. Haugland ${ }^{1}$, Anita Rønneseth ${ }^{1}{ }_{\text {, Heidrun I. Wergeland }}{ }^{1, *}$, \\ Ole Bent Samuelsen ${ }^{1,2}$
}

${ }^{1}$ Department of Biology, University of Bergen, Bergen High-Technology Centre, PO Box 7803, 5020 Bergen, Norway

${ }^{2}$ Institute of Marine Research, PO Box 1870 Nordnes, 5817 Bergen, Norway

\begin{abstract}
The granuloma disease caused by Francisella noatunensis subsp. noatunensis in farmed Atlantic cod has not been successfully treated by use of antibacterials, even when antibacterial resistance testing indicates a sufficient effect. The reason for this treatment failure may be the intracellular existence of the bacteria within immune cells, mainly macrophages. To investigate the effect of antibacterials on intracellular Francisella replication, we established a protocol for the detection of drugs within Atlantic cod immune cells using high-performance liquid chromatography (HPLC). When the uptake and intracellular concentrations of oxolinic acid and flumequine were analysed in isolated adherent head kidney leucocytes (HKLs) by HPLC, we found that uptake was rapid and the intracellular concentrations reflected the extracellular exposure concentrations. To investigate the effect of the antibacterial compounds on intracellular bacterial replication, adherent HKLs experimentally infected with the bacteria were analysed using flow cytometry and intracellular labelling of bacteria by specific antibodies. We found that flumequine did not inhibit intracellular bacterial replication. Unexpectedly, the results indicated that the intracellularly effiacy of the drug was reduced. The HPLC method used proved to be highly applicable for accurate determination of intracellular drug concentrations. When combined with sensitive and specific flow cytometry analyses for identification and measurement of intracellular bacterial replication, we suggest that this approach can be very valuable for the design of antibacterial treatments of intracellular pathogens.
\end{abstract}

KEY WORDS: Francisella noatunensis subsp. noatunensis · Intracellular replication · Antibacterials · Leucocytes $\cdot$ HPLC $\cdot$ Flow cytometry $\cdot$ Atlantic Cod $\cdot$ Gadus morhua

\section{INTRODUCTION}

According to statistics provided by the Norwegian Directorate of Fisheries, the production of cultivated Atlantic cod Gadus morhua L. has shown a steady decrease during recent years (www.fiskeridir.no/ statistikk/akvakultur/statistikk-for-akvakultur/andremarine-fiskearter). One of the reasons for this reduction has been the bacterium Francisella noatunensis subsp. noatunensis. This bacterium is a facultative

\footnotetext{
*Corresponding author: heidrun.wergeland@bio.uib.no
}

intracellular organism that causes francisellosis, a systemic granulomatous inflammatory disease. Francisellosis in Atlantic cod has been diagnosed since 2004 in clinically infected wild Atlantic cod and in Atlantic cod from aquaculture facilities spanning most of the Norwegian coastline from Rogaland to Nordland (Nylund et al. 2006, Olsen et al. 2006, Ottem et al. 2008, Zerihun et al. 2011). Mortality in farmed Atlantic cod associated with francisellosis varies, but loss of up to $40 \%$ of the stock has been

() The Authors 2014. Open Access under Creative Commons by Attribution Licence. Use, distribution and reproduction are unrestricted. Authors and original publication must be credited. 
registered (Olsen et al. 2006). Even though this disease has caused severe problems for years, no effective vaccine has been licensed, and no effective treatment with antibacterials has been presented.

Francisella noatunensis subsp. noatunensis has the ability to reside and replicate within Atlantic cod adherent head kidney leucocytes and can inhibit the potent killing mechanism known as respiratory burst (Vestvik et al. 2013). The existence within immune cells that normally eradicate bacteria shows that the bacterium has potent virulence mechanisms enabling its intracellular existence (Bakkemo et al. 2011, Furevik et al. 2011, Vestvik et al. 2013). The intracellular location of the bacteria will most likely protect them from antibacterial agents with poor penetration into phagocytic cells, and basic knowledge of the concentrations of antibacterial agents within Atlantic cod leucocytes is therefore needed. Furthermore, as antibacterial agents with high in vitro activity can be completely inactive against intracellular bacteria, exemplified by the aminoglycosides gentamycin and streptomycin (Vosbeck et al. 1984), it is also important to study the intracellular activity of antibacterials towards F. noatunensis subsp. noatunensis.

In order to make a theoretical assessment of a clinical outcome for an antibacterial agent towards a specific pathogen, data of the pathogen's minimum inhibitory concentration (MIC) values for that particular antibacterial is combined with data from pharmacokinetic investigations. Isachsen et al. (2012) found that 30 Norwegian isolates of Francisella noatunensis subsp. noatunensis were susceptible to only a few of the antibacterials tested, including florfenicol with an in vitro MIC of $0.5 \mu \mathrm{g} \mathrm{ml}^{-1}$ and flumequine and oxolinic acid, both with an in vitro $\mathrm{MIC}$ of $0.25 \mu \mathrm{g} \mathrm{ml}^{-1}$. Flumequine and oxolinic acid are both quinolones, bactericides with identical antibacterial mechanisms. Florfenicol, on the other hand, is bacteriostatic. Basic pharmacokinetic data are available for flumequine, oxolinic acid, florfenicol and a combination of ormetoprim and sulphadimetoxine (Romet ${ }^{30}$; Pharmag AS) in Atlantic cod (Hansen \& Horsberg 2000, Samuelsen et al. 2003a,b, 2006); however, even though leucocytes are present in blood, the organ with the highest density of leucocytes in Atlantic cod is the head kidney, for which no pharmacokinetic data are available. To predict the outcome of therapy for concentrationdependent bactericidal drugs that manifest a significant post-antibacterial effect, like the quinolones, the area under curve from $0-24 \mathrm{~h}\left(\mathrm{AUC}_{24}\right)$ divided by the MIC has been demonstrated to be most appropriate measure (AliAbadi \& Lees 2000, Smith 2008). AliAbadi \& Lees (2000) suggested an $\mathrm{AUC}_{24} / \mathrm{MIC}$ value greater than 100 and in some cases greater than 250. Isachsen et al. (2012) estimated that an oral dose of $25 \mathrm{mg} \mathrm{kg}^{-1}$ of oxolinic acid would give an $\mathrm{AUC}_{24} / \mathrm{MIC}$ value of 100, indicating efficacy, whereas for oral doses of 15 and $25 \mathrm{mg} \mathrm{kg}^{-1}$ of flumequine, $\mathrm{AUC}_{24}$ / MIC values of 262 and 276, respectively, were calculated. Therefore, due to the superior $\mathrm{AUC}_{24} / \mathrm{MIC}$ value of flumequine, this drug was chosen for the effect study. Flumequine, oxolinic acid and florfenicol have all proven highly effective in treating infections caused by extracellular bacteria in Atlantic cod (Samuelsen \& Bergh 2004, Vik-Mo et al. 2005, Seljestokken et al. 2006), whereas oxolinic acid and florfenicol are at present the 2 most used antibacterials in treating bacterial infections in Atlantic salmon Salmo salar in Norway (statistic from Norwegian Institute of Health, www.fhi.no/).

Here we examined the in vitro uptake of flumequine and oxolinic acid in adherent head kidney leucocytes (HKLs) of Atlantic cod at 2 concentrations and the effect of flumequine on bacterial cell division inside the HKLs. Furthermore, the head kidney/plasma ratio of oxolinic acid and flumequine were determined following a single intraperitoneal injection.

\section{MATERIALS AND METHODS}

\section{Fish}

Healthy, non-vaccinated Atlantic cod Gadus morhua L. (100-200 g) were obtained from Fjord Gadus AS, Norway, and kept in 5001 tanks in the rearing facilities at Bergen High-Technology Centre at a temperature of $8{ }^{\circ} \mathrm{C}$, salinity of $34 \%$ and $24 \mathrm{~h}$ light. Water flow was adjusted to maintain $>77 \%$ oxygen saturation in the outlet water, and the fish were fed commercial dry feed (Skretting) for marine species. The weight of the fish was used in the experiments was in the range of 240 to $540 \mathrm{~g}$, and the fish showed no signs of infection.

\section{Isolation of leucocytes}

Atlantic cod were randomly sampled and killed by a blow to the head. Leucocytes were isolated as previously described for Atlantic cod (Rønneseth et al. 2007). Briefly, the head kidney ( $\mathrm{HK}_{;} 0.8$ to $1.5 \mathrm{~g}$ ) was removed and placed in $2 \mathrm{ml}$ of Leibovitz L-15+ solution (L-15; Lonza) adjusted to 370 mOsm by adding $5 \%(\mathrm{v} / \mathrm{v})$ of a solution of $0.41 \mathrm{M} \mathrm{NaCl}, 0.33 \mathrm{M}$ $\mathrm{NaHCO}_{3}, 0.66 \%$ (w/v) D-glucose, $10 \mathrm{U} \mathrm{ml}^{-1}$ heparin 
(Sigma-Aldrich) and $15 \mathrm{mM}$ HEPES. HK cell suspensions were obtained by gently forcing the tissue through a cell strainer of $100 \mu \mathrm{m}$ (Becton Dickinson/ Falcon) followed by dilution in L-15+ to a total volume of $5 \mathrm{ml}$. The cell suspensions were placed on discontinuous Percoll gradients $\left(3 \mathrm{ml}, 1.070 \mathrm{~g} \mathrm{ml}^{-1}\right)$ overlaid with $2.5 \mathrm{ml}\left(1.050 \mathrm{~g} \mathrm{ml}^{-1}\right)$ and centrifuged at $400 \times g\left(40 \mathrm{~min}\right.$ at $\left.4^{\circ} \mathrm{C}\right)$. The leucocyte fraction was collected from the interface of the 2 Percoll densities including the downward density layer, and washed by diluting the cell suspension in L-15+ and centrifugation at $200 \times g\left(10 \mathrm{~min}\right.$ at $\left.4^{\circ} \mathrm{C}\right)$. The cells were resuspended in L-15+ and counted using a CASY Cell Counter ${ }^{\mathrm{TM}}$ (Innovatis AG). The viability and aggregation factor for all isolated cell suspensions were determined according to the manufacturer's protocol. HKLs showing viability of $94 \%$ or above and a cell aggregation factor below 1.2 were used in the study.

\section{In vitro absorption of flumequine and oxolinic acid by adherent HKLs}

Stock solutions of flumequine and oxolinic acid (Norsk Medisinaldepot) were prepared at a concentration of $1.0 \mathrm{mg} \mathrm{ml}^{-1}$ in methanol and stored at $-20^{\circ} \mathrm{C}$. Working standards were prepared by dilution from the stock solutions in diluted alkali $(0.025 \mathrm{M}$ $\mathrm{NaOH})$ or L-15+ medium.

Leucocytes in L-15+ medium $\left(300 \mu \mathrm{l}, 5 \times 10^{7}\right.$ cells $\mathrm{ml}^{-1}$ ) were added to a 48-well tissue culture plate (Polystyrene Nunclon Delta Surface, Thermo Fisher Scientific Nunc AS) and sealed with tape (Microseal@ B-Film, Bio-Rad Laboratories). After $2 \mathrm{~h}$ incubation at $12^{\circ} \mathrm{C}$, non-adherent cells were removed and L-15+ medium containing $5 \%(\mathrm{v} / \mathrm{v})$ foetal bovine serum (FBS; Lonza) was added. The cells were further incubated at $12^{\circ} \mathrm{C}$ for a total of $24 \mathrm{~h}$ followed by removal of media and washing of the adherent cells with L-15 medium. Oxolinic acid and flumequine were diluted in L-15 medium containing $5 \%$ FBS to concentrations of 5.0 and $10 \mu \mathrm{g} \mathrm{ml}^{-1}$, and $300 \mu \mathrm{l}$ were added to each well and incubated at $12^{\circ} \mathrm{C}$.

The selected drugs and concentrations were based upon pharmacokinetic studies and MIC values of Francisella noatunensis subsp. noatunensis (Isachsen et al. 2012). During incubation, the wells were covered by sealing tape as described above and wrapped in tinfoil to avoid photo-degradation of the antibacterials. Flumequine and oxolinic acid are weak acids, and the absorption into cells is dependent on the degree of ionization (Burka et al. 1997).
The $\mathrm{pH}$ in the solutions was therefore measured using an Orion 2 star Benchtop pH meter and in all test wells after incubation using $\mathrm{pH}$-indicator strips (Merck). Six parallel samples were collected at time $0,0.5,1,2$ and $4 \mathrm{~h}$ post administration. Following sampling, the wells with adherent cells were washed 3 times in L-15+ to remove extracellular flumequine and oxolinic acid. Wells without antibacterial agents served as negative controls. The numbers of adherent cells in controls were $1 \times 10^{6}$ per well.

For sample preparation, to each well with adherent leucocytes we added $150 \mu \mathrm{l}$ acetonitrile (Merck) for lysis of the cells followed by $130 \mu \mathrm{l} 0.025 \mathrm{M} \mathrm{NaOH}$, $10 \mu \mathrm{lnCl} \mathrm{ZnC}_{2}(10 \% \mathrm{v} / \mathrm{v})$ and $10 \mu \mathrm{l}$ internal standard solution (10 $\mathrm{\mu g} \mathrm{ml}^{-1}$ in $0.025 \mathrm{M} \mathrm{NaOH}$ solution). After vortexing (MS2 Minishaker, IKA-Werke) for $1 \mathrm{~min}$ followed by centrifugation at $14930 \times g$ for $5 \mathrm{~min}$ (Beckman Microfuge ${ }^{\circledR}$ Lite, Beckman Coulter) using a Spin-X Micro Centrifuge filter (0.2 $\mu \mathrm{m}_{i}$ Corning), a clear supernatant was obtained ready for analysis.

Samples of drug-free adherent leucocytes were prepared as described above and analysed to confirm the absence of flumequine and oxolinic acid. Standard curves for flumequine and oxolinic acid in leucocytes covering the range of 1.25 to $10.0 \mathrm{\mu g} \mathrm{ml}^{-1}$ were prepared in triplicate. Oxolinic acid was used as an internal standard for flumequine and vice versa.

\section{In vivo distribution of flumequine and oxolinic acid}

Two groups of 10 Atlantic cod each were administered an intraperitoneal dose of approximately $12.5 \mathrm{mg} \mathrm{kg}^{-1}$ of oxolinic acid and flumequine. The weight of the fish varied from 244 to $540 \mathrm{~g}$, and the seawater temperature was $8^{\circ} \mathrm{C}$. The fish were killed by a blow to the head $48 \mathrm{~h}$ after medication, and samples of plasma and HK were obtained and kept at $-20^{\circ} \mathrm{C}$ until analysed. Samples of HK were prepared for drug residue analysis following the procedure described by Samuelsen et al. (1999). Plasma samples $(100 \mu l)$ were prepared in the same way as the leucocytes (Samuelsen et al. 1999).

Samples of HK were weighed, homogenized in $1.0 \mathrm{ml}$ of $0.05 \mathrm{M}$ Tris $\mathrm{HCl}$ buffer ( $\mathrm{pH} 8.0$ ), amended with $1 \mathrm{ml}$ of acetonitrile containing the internal standard and $30 \mu \mathrm{l} \mathrm{ZnCl}_{2}(10 \% \mathrm{v} / \mathrm{v})$, shaken and kept in the dark at $4^{\circ} \mathrm{C}$ overnight. After centrifugation at $14930 \times g$ for 5 min in a Spin-X Micro Centrifuge filter $(0.2 \mu \mathrm{m})$, the samples were ready for analysis. Samples of plasma and HK from 3 unmedicated fish were taken prior to initiation of the study and ana- 
lysed to confirm the absence of flumequine and oxolinic acid. Standard curves for oxolinic acid and flumequine in the range of 0.1 to $10.0 \mu \mathrm{g} \mathrm{g}^{-1}\left(\mathrm{ml}^{-1}\right)$ were prepared in triplicate.

\section{High-performance liquid chromatography (HPLC)}

Flumequine and oxolinic acid were obtained from Norsk Medisinaldepot. Methanol, acetonitrile, tetrahydrofuran (HPLC-grade) and oxalic acid dihydrate, Tris, $\mathrm{HCl}_{1} \mathrm{NaOH}$ and $\mathrm{ZnSO}_{4}$ (pa-grade) were all from Merck.

The concentration of flumequine and oxolinic acid in the samples was determined using HPLC. The HPLC system consisted of a Spectra-Physics SP 8800 ternary HPLC pump connected to a Spectra-Physics SP 8780 X R Autosampler and a Shimadzu RF-535 fluorescence detector operating at an excitation wavelength of $325 \mathrm{~nm}$ and an emission wavelength of $360 \mathrm{~nm}$. The detector output was coupled to a computerized data system consisting of a Dionex UCI-50 Universal Chromatography Interface, the program Dionex Chromeleon Version 6.80 (Dionex Softron) and a PP04X Dell computer for storage and integration of the chromatograms. The analytical column was a $150 \times 4.6 \mathrm{~mm}$ Zorbax SB-C8 $3.5 \mu \mathrm{m}$ (Agilent Technologies) connected to a short C-8 pre-column $(10 \times 4.6 \mathrm{~mm})$. The column was operated at room temperature. The mobile phase used contained (A) $0.025 \mathrm{M}$ oxalic acid pH 3.2 - acetonitrile - methanol - tetrahydrofuran $(70-7.5-20-2.5 \mathrm{v} / \mathrm{v})$ and $(\mathrm{B})$ $0.025 \mathrm{M}$ oxalic acid pH 3.2 - acetonitrile - methanol - tetrahydrofuran $(50-20-25-5 \mathrm{v} / \mathrm{v})$. The elution profile was as follows: 0-4 min isocratic $50 \% \mathrm{~B}$; 4.1-10 min 50-100\% B linear gradient; $10.1-15 \mathrm{~min}$ isocratic $100 \% \mathrm{~B} ; 15.1-20 \mathrm{~min}$. isocratic $50 \% \mathrm{~B}$. The injection volume was $20 \mu \mathrm{l}$ and flow rate $1 \mathrm{ml} \mathrm{min}^{-1}$, giving elution times of approximately $6.2 \mathrm{~min}$ for oxolinic acid and $8.7 \mathrm{~min}$ for flumequine.

\section{Bacteria}

The Francisella noatunensis subsp. noatunensis strain used in this study (NCMB 14265 ${ }^{\mathrm{T}}$ ) was isolated from farmed Atlantic cod (Mikalsen et al. 2007) and supplied by Dr. Colquhoun at the National Veterinary Institute, Oslo, Norway. Bacteria were grown as described by Furevik et al. (2011) using Bacto ${ }^{\mathrm{TM}} \mathrm{Eu}$ gon Broth (Becton-Dickson) containing $2 \mathrm{mM} \mathrm{FeCl}_{3}{ }^{*}$ $6 \mathrm{H}_{2} \mathrm{O}$ (Sigma-Aldrich) at $20^{\circ} \mathrm{C}$ with gentle shaking (150 rpm). A growth curve was established by meas- uring optical density at $600 \mathrm{~nm}\left(\mathrm{OD}_{600 \mathrm{~nm}}\right)$ using a Hitachi U-1100 spectrophotometer. Bacteria in the exponential growth phase were harvested at $\mathrm{OD}_{600 \mathrm{~nm}}$ between 1.5 and 1.8 and diluted to an $\mathrm{OD}_{600 \mathrm{~nm}}$ of 0.2 using L-15+ and left at $20^{\circ} \mathrm{C}$ with gentle shaking $(150 \mathrm{rpm})$ for a maximum of $1 \mathrm{~h}$ until used for challenge of leucocytes.

\section{In vitro infection of macrophages}

For analysis of intracellular replication, adherent HKLs $24 \mathrm{~h}$ after seeding were exposed to bacteria. Cells were prepared as described above and $1.3 \times$ $10^{8}$ cells were added per well (24-well plate). The growth medium was removed from the wells, and $1 \mathrm{ml}$ of the bacterial suspension $\left(\mathrm{OD}_{600}=0.2\right)$ was added followed by incubation for $4 \mathrm{~h}$ at $12^{\circ} \mathrm{C}$. After incubation, extracellular bacteria were removed by washing in L-15+ followed by addition of L-15+ with FBS and subsequent incubation. The bacterial dose used for infection was based upon previous studies (Furevik et al. 2011). In non-infected controls, only L-15+ medium was added to the wells. After further incubation for 4 or $20 \mathrm{~h}$ (later termed 4 and $20 \mathrm{~h}$ post infection, hpi), the adherent HKLs were detached by gentle trypsination using $200 \mu \mathrm{l}$ of a mixture of Trypsin-Versene EDTA (Lonza) and gentle scraping with a bent glass pipette. To remove extracellular bacteria, the cell suspension was placed on top of a cushion consisting of $3 \mathrm{ml}$ phosphate-buffered saline (PBS) $\mathrm{pH} 7.3$, with $3 \%(\mathrm{w} / \mathrm{v})$ bovine serum albumin (BSA) (Sigma-Aldrich) and $4.5 \%$ (w/v) D-glucose as previously described (Chilmonczyk \& Monge 1999, Li et al. 2004) and centrifuged at $100 \times g(10 \mathrm{~min}$ at $4^{\circ} \mathrm{C}$ ). The number of adherent cells per well was $4 \times$ $10^{6}(4 \mathrm{hpi})$ and $3.9 \times 10^{6}(20 \mathrm{hpi}$; mean of 4 parallels from each of 4 fish at each sampling). After centrifugation, the cells were resuspended in PBS 380 mOsm to a concentration of $2.5 \times 10^{6} \mathrm{ml}^{-1}$. Cell numbers and viability were analysed using a CASY Cell Counter $^{\mathrm{TM}}$ as described earlier.

\section{Intracellular replication of bacteria analysed by flow cytometry}

For detection of intracellular bacteria, leucocytes were fixed and permeabilized as previously described (Rønneseth et al. 2012, 2013, Vestvik et al. 2013) using a Becton Dickinson (BD) Cytofix/Cytoperm ${ }^{\mathrm{TM}}$ Fixation/Permeabilization kit (BD Biosciences), which is based on paraformaldehyde $(4 \%)$ for fixation and 
saponin for permeabilization. The leucocyte pellet of $1 \times 10^{6}$ cells ml ${ }^{-1}$ per tube was suspended in $50 \mu \mathrm{l}$ of PBS (380 OsM) to which $500 \mu$ l fixative were added. The tubes were incubated for $20 \mathrm{~min}$ on ice with gentle cycles using a Grant-bio PS-M3D (Grant Instruments). Following incubation, the cells were centrifuged at $400 \times g$ for 4 min (Beckman GPR Centrifuge), the supernatant was discarded, and the pellet was resuspended in $900 \mu \mathrm{l}$ of the BD perm/wash solution followed by a second centrifugation at $400 \times g$ for $4 \mathrm{~min}$, decantation of the supernatant and resuspension in $200 \mu \mathrm{l}$ of the BD perm/wash solution. For the flow cytometry analyses of intracellular bacteria, $250 \mathrm{\mu l}$ rabbit anti-Francisella noatunensis subsp. noatunensis serum, provided by Dr. Colquhoun at the National Veterinary Institute, Oslo (diluted 1:30 000 in $\mathrm{BD}$ perm/wash solution) were added to the suspension, followed by incubation for $1 \mathrm{~h}$ on ice at gentle tilting, washing twice in perm/wash solution and resuspension of the pellet in $150 \mu \mathrm{l}$ Alexa Fluor 647 conjugated goat anti-rabbit antibody (Life Technologies; diluted 1:400 in perm/wash solution). After incubation for $45 \mathrm{~min}$ on ice with gentle tilting, followed by 2 washings in perm/wash before resuspending the pellets in $500 \mu \mathrm{l}$ PBS supplemented with $1 \%(\mathrm{w} / \mathrm{v}) \mathrm{BSA}$ and 25 mM EDTA (Sigma-Aldrich; $\mathrm{pH}=7$ ), the samples were ready for flow cytometry analysis.

For investigation of the effect of flumequine on intracellular bacterial replication, the adherent cells were exposed to bacteria for $4 \mathrm{~h}$ at $12^{\circ} \mathrm{C}$, after which the supernatant was removed and the cells washed with L-15 medium to remove extracellular bacteria. Flumequine $\left(500 \mu \mathrm{l}, 5 \mathrm{\mu g} \mathrm{ml}^{-1}\right)$ in L-15+ containing $5 \%$ FBS was added to each well and incubated in the dark as described previously. The samples were prepared and analysed by flow cytometry as described above after 4 and $20 \mathrm{~h}$ of incubation. The concentration of flumequine used was based on results from the in vitro absorption experiment and previously published pharmacokinetic data (Vik-Mo et al. 2005), giving a post-treatment period with a concentration above MIC of $9 \mathrm{~d}$.

Non-infected cells treated exactly in the same way as Francisella noatunensis-infected cells served as controls. Rabbit pre immune serum was used as the isotype control, and rabbit serum was omitted to test for specific binding of Alexa Fluor goat anti rabbit IgG.

Two parallels were used throughout all analyses, and controls were performed on cells from the same fish as test samples. The threshold for positive cells (infected) was set to be above $1 \%$ of non-infected controls to avoid false positives.
Flow cytometry analyses were performed using a BD FACSCalibur (BD Biosciences) flow cytometer equipped with a $635 \mathrm{~nm}$ red diode laser, using Cell Quest version 5.2.1 software (BD Biosciences). Cells were analysed for forward and sideward scatter patterns, representing the size and granularity of the cells, respectively, and for red fluorescence (FL4). From each sample, 10000 cells were recorded. For analyses of data, FCS express 3 software (De Novo Software) was used.

\section{Immunostaining of bacteria within leucocytes for microcopy}

Infected leucocytes and non-infected controls were washed 3 times in PBS and fixed in $1 \mathrm{ml}$ of $3.7 \%$ (w/v) paraformaldehyde (Sigma-Aldrich), and the cell membrane was permeabilized by $0.1 \%$ (v/v) Triton X-100 as described by Furevik et al. (2011). One $\mathrm{ml}$ rabbit-anti-Francisella noatunensis serum (diluted 1:30000 in PBS containing 0.5\% w/v BSA) was added to each well and incubated for $1 \mathrm{~h}$ at $18^{\circ} \mathrm{C}$. Rabbit pre immune serum was used to control for specificity. Infected cells without primary rabbit antiserum were also analysed to verify specificity of the antiserum to the bacteria. The samples were washed 3 times for $5 \mathrm{~min}$ in PBS and amended with $1 \mathrm{ml}$ Alexa Fluor ${ }^{\circledR} 555 \mathrm{~F}\left(\mathrm{ab}^{\prime}\right)_{2}$ fragment, goat anti-rabbit IgG (Life Technologies) diluted 1:400 in PBS and incubated for $45 \mathrm{~min}$ at $18^{\circ} \mathrm{C}$. Following 2 rinses (5 min each) in PBS, actin was stained using Alexa Fluor ${ }^{\circledR} 488$ phalloidin (Life Technologies). A solution of $5 \mathrm{\mu l}$ Alexa Fluor ${ }^{\circledR} 488$ phalloidin (Molecular probes, Invitrogen) diluted in $200 \mu \mathrm{l}$ PBS with $1 \%$ $(\mathrm{w} / \mathrm{v}) \mathrm{BSA}$ was added and the samples incubated at $18^{\circ} \mathrm{C}$ for $20 \mathrm{~min}$. Excess phalloidin was removed by washing twice with PBS. The slide preparations were air dried and coverslipped with ProLong Gold antifade containing 4', 5-diamidino-2-phenylindole (DAPI; Life Technologies). For confocal microscopy, $200 \mu \mathrm{l}$ of a $300 \mathrm{nM}$ DAPI solution were added to each well for nuclear staining. Prior to microscopy, all slides were kept in the dark at $4^{\circ} \mathrm{C}$ for $12 \mathrm{~h}$.

\section{Microscopy and statistics}

Immunostained cell samples were examined using a Zeiss Axioskop 2 plus fluorescence microscope, whereas confocal microscopy was performed at the Molecular Imaging Centre at the University of Bergen using a Zeiss LSM 510 Meta confocal micro- 
scope. Overlays of images were prepared using Adobe photoshop CS2, version 9.0 (Adobe Systems). Statistical analyses of the data were performed using the program Prism 5 (Graph Pad).

\section{RESULTS}

\section{Leucocytes and effect of drug exposure}

Based on high \% viability of cells (>94\%) and a low aggregation factor $(<1.2)$, the quality of both the isolated and adherent HKLs was classified as very good after 4 and $20 \mathrm{~h}$, even after exposure to the drugs. The scatterplots of cells, with or without drug exposure, show that flumequine had no effect on cell size or granularity (Fig. 1). The phalloidin staining of the adsorbed drug-exposed cells also verified the quality of the cells as shown for non-infected and infected cells in Fig. 2.

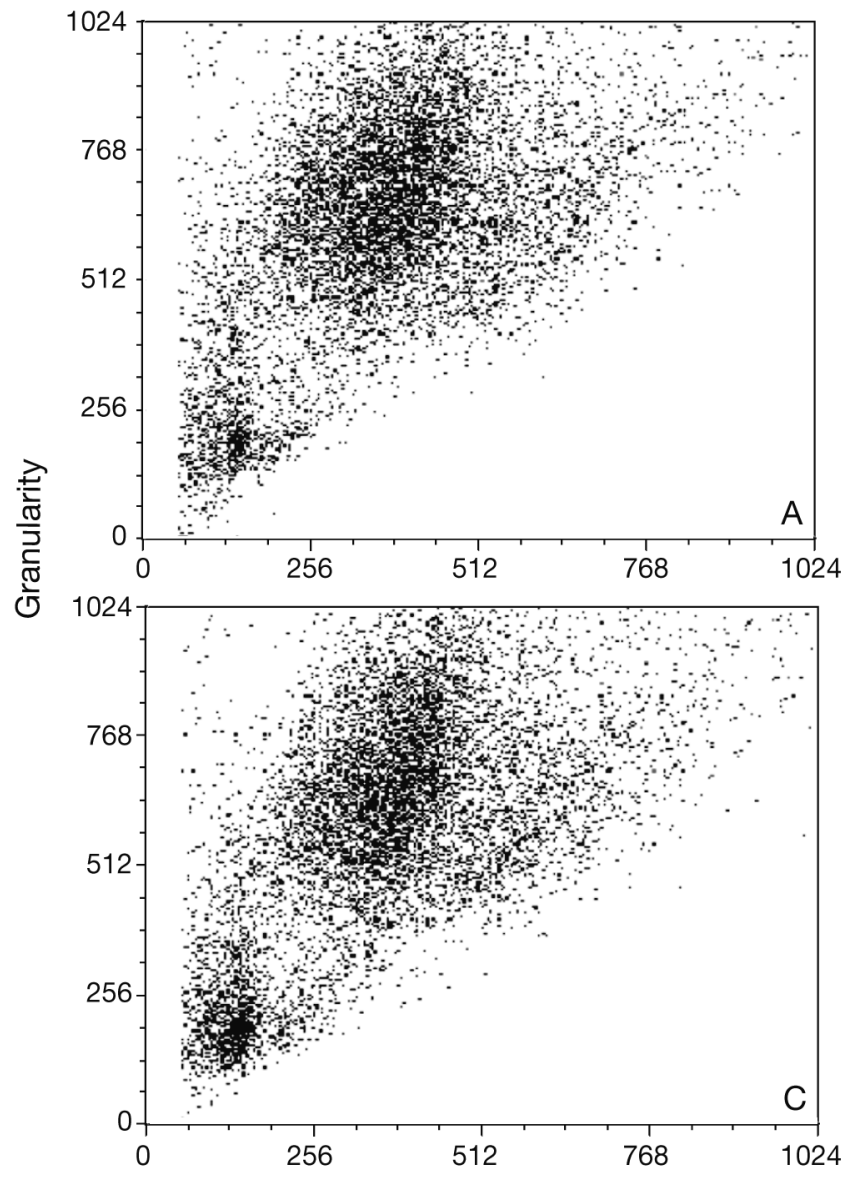

After addition of flumequine or oxolinic acid (5 and $10 \mu \mathrm{g} \mathrm{ml}^{-1}$ ), the $\mathrm{pH}$ in the cell growth medium was in the range of 7.4 to 7.7 using $\mathrm{pH}$ indicator strips and 7.60 to 7.66 using the $\mathrm{pH}$ meter.

\section{Concentrations of flumequine and oxolinic acid}

In the drug-free samples of leucocytes, plasma and HK, no interfering peaks were seen in the area of the HPLC chromatogram in which the drugs should appear. The standard curves were linear over the range studied, with $\mathrm{r}^{2}=0.996$ and 0.999 , respectively, for oxolinic acid and flumequine as shown in Fig. 3A,B for adherent leucocytes. The uptake of oxolinic acid and flumequine in $\mathrm{HK}$ adherent leucocytes over time is shown in Fig. 3C-F. For both drugs, the uptake was rapid, with high intracellular concentrations after $0.5 \mathrm{~h}$ of exposure followed by a drop at $1 \mathrm{~h}$ and then moving towards concentrations similar
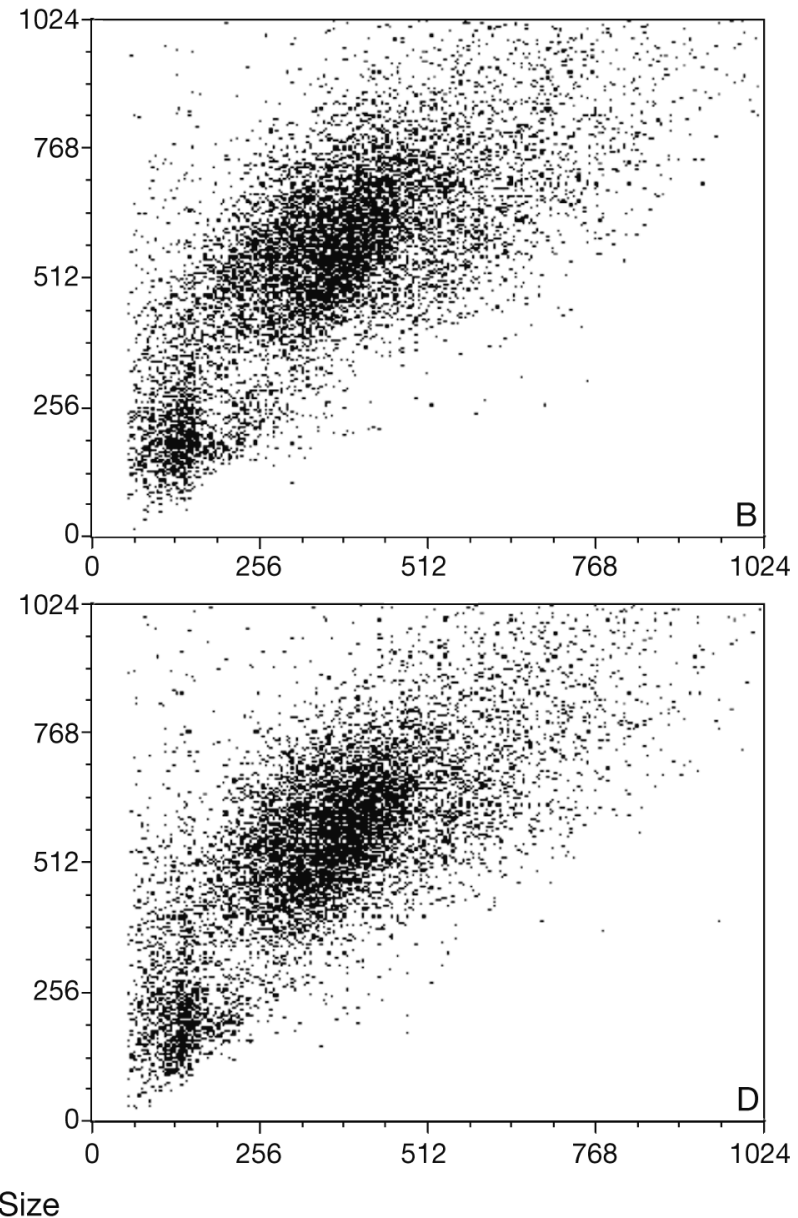

Fig. 1. Gadus morhua. Flow cytometry scatterplots showing the distribution of adherent head kidney leucocytes (HKLs) after $(A, C) 4 \mathrm{~h}$ and $(\mathrm{B}, \mathrm{D}) 20 \mathrm{~h}$ incubation in wells in the $(\mathrm{A}, \mathrm{B})$ absence or $(\mathrm{C}, \mathrm{D})$ presence of flumequine 

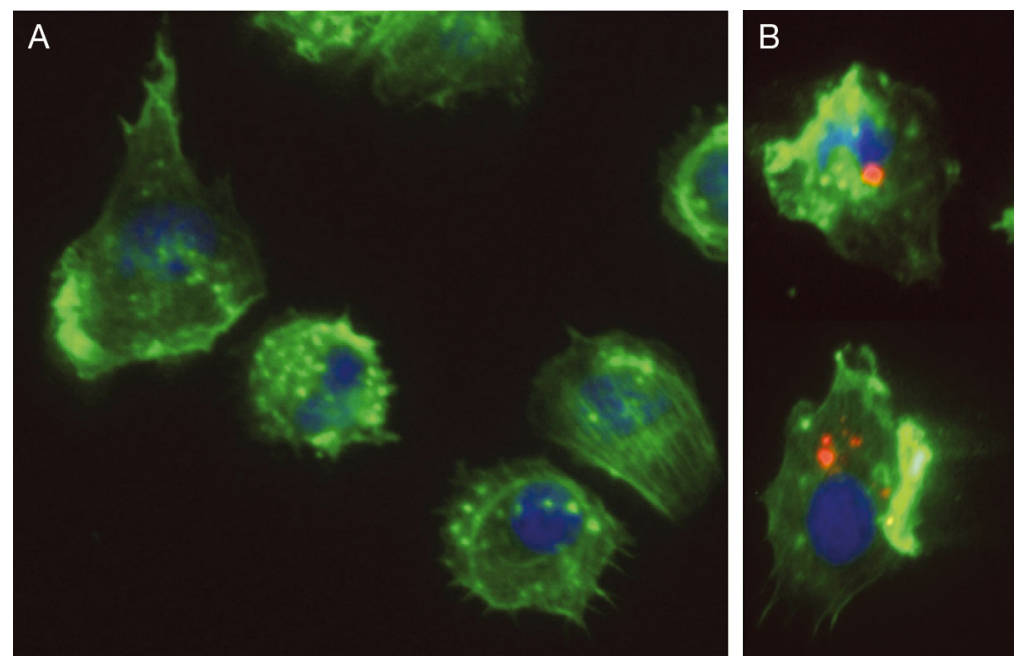

Fig. 2. Gadus morhua leucocytes infected by Francisella noatunensis subsp. noatunensis. Adherent head kidney leucocytes stained by Alexa Fluor® 488 phalloidin (green). (A) Non-infected cells and (B) the bacteria (4 h post infection) and immunostained with rabbit antiserum (red). Nuclei are stained blue by DAPI. The infected cells are confocal mid sections showing the intracellular presence of the bacteria. The photos were captured through a $63 \times$ objective
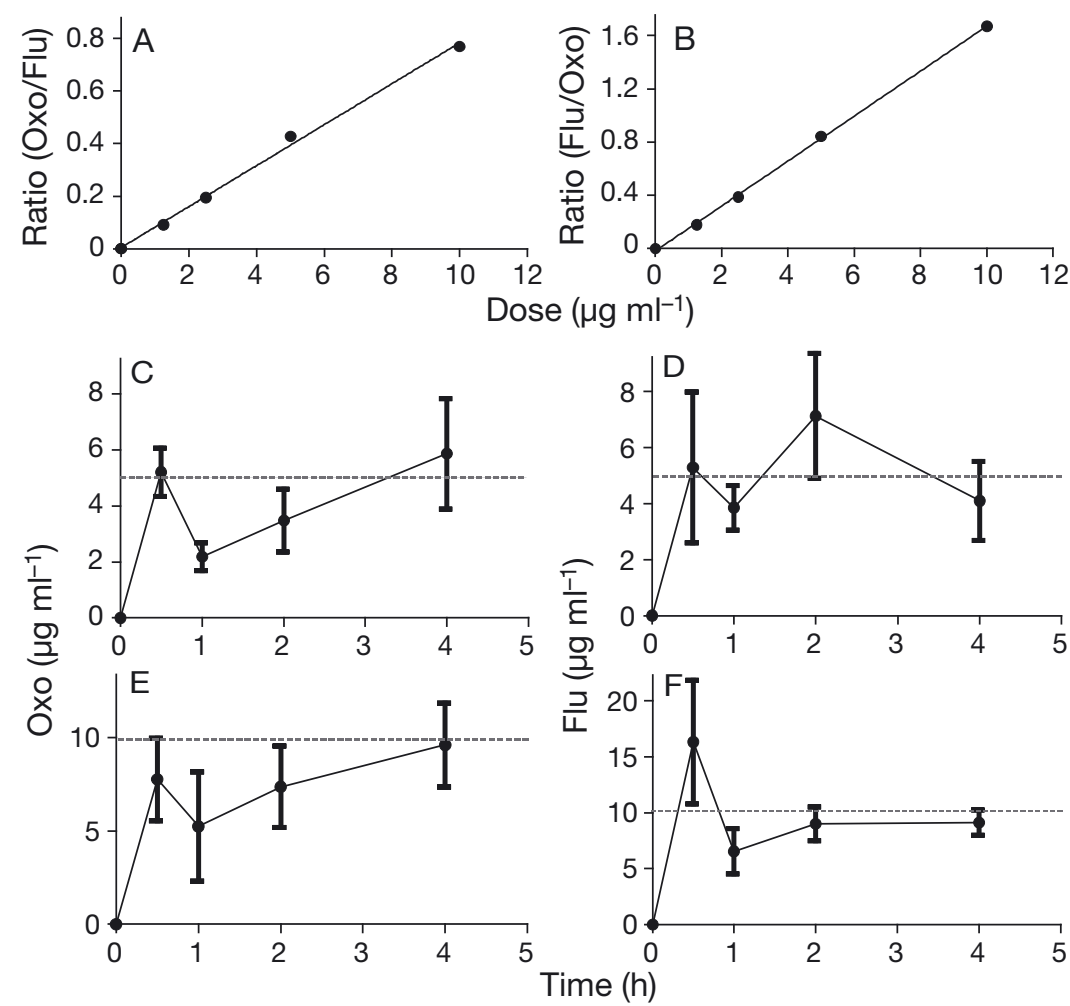

Fig. 3. Gadus morhua. In vitro absorbance of oxolinic acid and flumequine by adherent head kidney leucocytes (HKLs) was determined by HPLC analyses. The standard curves are shown for (A) oxolinic acid (Oxo) and (B) flumequine (Flu). The intracellular concentration at various times after exposure to $(C, D) 5$ and $(E, F) 10 \mu \mathrm{g} \mathrm{ml}^{-1}$ of $(C, E)$ oxolinic acid or $(D, F)$ flumequine. Dashed horizontal lines show the concentration (5 or $10 \mu \mathrm{g} \mathrm{ml}^{-1}$ ) of the drug in the cell culture medium. Vertical bars show SD to the concentration in the external cell culture medium.

After in vivo administration, drug concentrations were measured in HK tissue and serum samples from Atlantic cod. Based on 15 parallels for each drug, we calculated HK/plasma ratios of 1.15 and 1.40 , respectively, for flumequine and oxolinic acid.

\section{Bacterial replication in HKLs after exposure to drugs}

The flow cytometry analyses of intracellular replication of Francisella noatunensis subsp. noatunensis were performed 4 and $20 \mathrm{hpi}$. The results show the number of infected cells in Fig. 4A,E for cells exposed to $5 \mu \mathrm{g} \mathrm{ml}$ flumequine and Fig. 4B,F for non-exposed cells. The location of the infected cells in the dot plot shows that mainly large granular cells were infected. The corresponding histograms show that with the drug present, $8.2 \%$ of the cells contained intracellular bacteria after 4 $\mathrm{h}$ and $6.2 \%$, when cells were incubated without flumequine (Fig. 4C,D). After $20 \mathrm{~h}$, the corresponding values were $17.3 \%$ with and $13.4 \%$ without flumequine (Fig. 4G,H). The intracellular replication is shown both by the increased fluorescence intensity and in scatterplots at $20 \mathrm{hpi}$. The infected cells were still the large granular cells, and the number of infected cells had increased in samples both with and without flumequine. The proportion of infected cells (mean value calculated from 4 fish) at 4 hpi was 7.9 and $8.3 \%$ with and without flumequine, respectively. At 20 hpi, 10.2 and $10.3 \%$ of cells were infected with and without flumequine, respectively. At $20 \mathrm{hpi}$, higher individual values were found compared with 4 hpi (Fig. 5). The mean and SD also show that individual variations were present, and on an individual level, the differences shown in the scatterplots are representative (Fig. 4). Photos of the microscopy slides of noninfected cells and infected cells are 

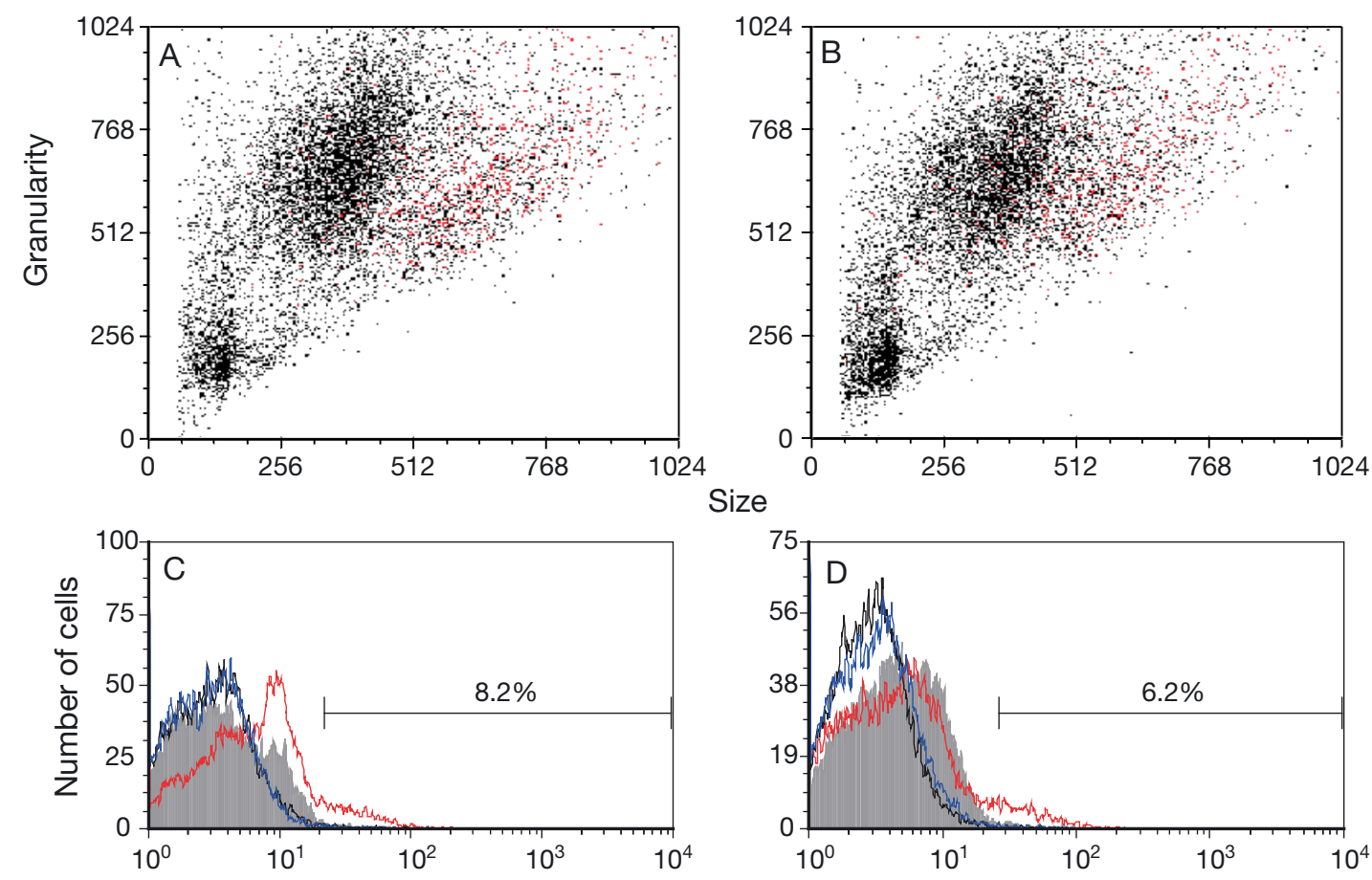

Alexa fluor 647
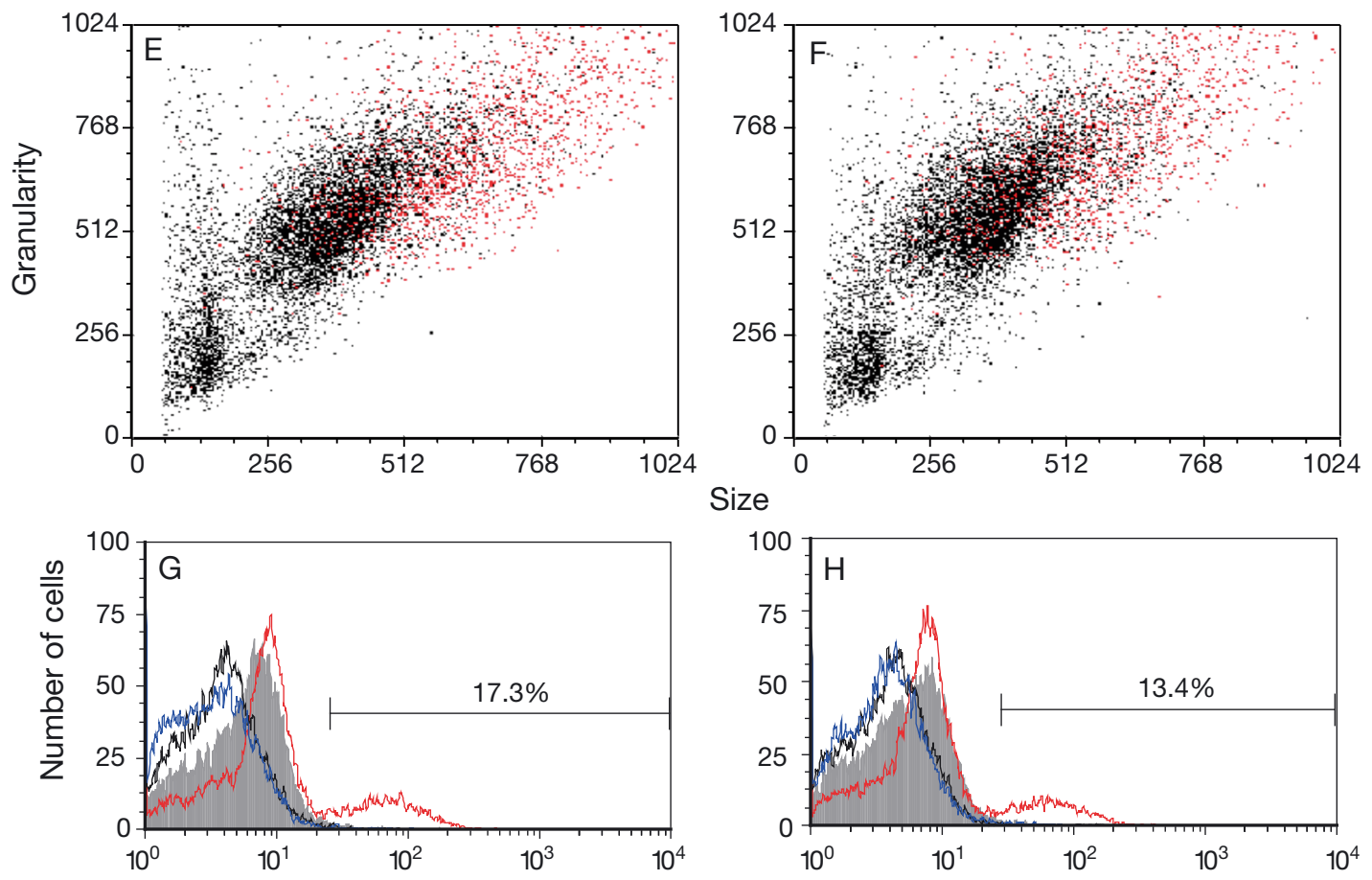

Alexa fluor 647

Fig. 4. Gadus morhua leucocytes infected by Francisella noatunensis subsp. noatunensis. Effect of flumequine on infection in adherent head kidney leucocytes (HKLs) analysed by flow cytometry. Representative scatterplots of F. noatunensis-infected adherent HKLs in the presence of flumequine $\left(5 \mu \mathrm{g} \mathrm{ml}^{-1}\right)$ at (A) 4 and (E) $20 \mathrm{~h}$ post infection (hpi) show the number of infected cells (red dots) and the increase in infected cells over time. Black dots: non-infected cells. The corresponding results where no flumequine was added are shown for (B) 4 and (F) 20 hpi. The threshold for positive cells (infected) was set to be above $1 \%$ in non-infected controls. Histograms show percentages of infected cells at (C) 4 and (G) 20 hpi with flumequine and at (D) 4 and $(\mathrm{H}) 20$ hpi without flumequine. Grey, filled area: non-infected cells; black line: non-infected cells, isotype control; blue line: infected cells, isotype control; red line: infected cells 


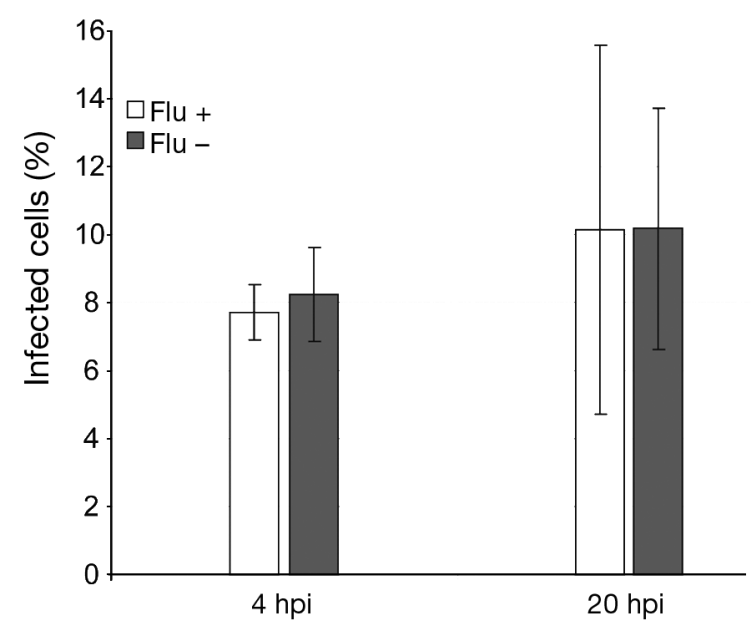

Fig. 5. Gadus morhua leucocytes. Mean \pm SD percentages of infected cells 4 and $20 \mathrm{~h}$ post infection (hpi), with (white bars) and without (grey bars) flumequine (Flu), from 4 different fish

shown in Fig. 2, and confocal sections confirm the intracellular existence of the bacteria (Fig. 2B).

\section{DISCUSSION}

In this study we examined the cellular uptake of flumequine and oxolinic acid using HPLC and studied the antibacterial activity of flumequine against Francisella noatunensis subsp. noatunensis within Atlantic cod macrophages using flow cytometry for detection of intracellular bacteria. We found that even intracellular concentrations of flumequine well above MIC did not prevent replication of the bacterium.

The intracellular pharmacodynamics in fish leucocytes or other fish cell types has not yet been described for drugs used in aquaculture. However, disease challenges caused by various intracellular fish pathogenic bacteria like Francisella noatunensis, Renibacterium salmoninarum and Piscirickettsia salmonis (Gutenberger et al. 1997, Fryer \& Hedrick 2003, Birkbeck et al. 2011) make such analyses highly relevant in order to develop effective treatment strategies.

We found that the uptake of both drugs was rapid in leucocytes, and during the experimental period of $4 \mathrm{~h}$, the concentration of oxolinic acid and flumequine moved towards equilibrium with the external concentration in the media. This is consistent with passive diffusion as the main mechanism for uptake. However, the high concentrations obtained after $0.5 \mathrm{~h}$ especially for flumequine as shown in Fig. 3 indicate that other mechanisms such as pinocytosis may be involved and may be dominant early in the absorption process. Consequently, when equilibrium has been reached, one might predict that the concentration in leucocytes will be reflected by the external concentration of flumequine and oxolinic acid in the surrounding fluid or organ. In general, fluoroquinolones have a fast in- and outflux of cells, which our results confirm, although a much higher intracellular accumulation, 7 - and 8-fold at equilibrium, has been described for ciprofloxacin and moxifloxacin, respectively, in human macrophages (Carryn et al. 2003). The differences concerning intra- versus extracellular concentrations may reflect both differences between human and Atlantic cod macrophages and pharmacokinetic differences between quinolones.

Our analyses were performed using plastic adherent leucocytes from HK of Atlantic cod, and most of these cells are likely monocytes/macrophages, but we cannot exclude that other cell types are present since we lacked cell-specific markers. Our study showed that the bacterium infected and replicated well within these cells, and the results concerning the infection pattern were in full accordance with earlier findings where intracellular bacteria were dispersed in the cytosol $24 \mathrm{hpi}$ and intracellular replication was shown (Furevik et al. 2011, Vestvik et al. 2013).

The initial number of leucocytes added to the wells was constant. However, since the number of leucocytes that adhered was not measured, this can vary to some extent due to individual variations and may be a factor that contributes to the variation seen between parallel samples in Fig. 3. Flumequine and oxolinic acid have pKa values of 6.65 and 6.78 , respectively (Jimenez-Lozano et al. 2002), whereas the $\mathrm{pH}$ in the external medium was measured to be in the range of 7.60 to 7.66 . In Atlantic cod plasma, the $\mathrm{pH}$ is approximately 7.4. We can therefore conclude that although the major part of the drugs was in an ionic form, a satisfactory uptake to leucocytes occurred.

Leucocytes are present in blood, but the organ with the highest density of leucocytes in Atlantic cod is the HK. Pharmacokinetic data exist for oxolinic acid and flumequine in plasma but not in HK. In this study, an HK/plasma ratio of 1.16 for flumequine and 1.40 for oxolinic acid were found $48 \mathrm{~h}$ following in vivo administration. If accepting the assumption that the HK/plasma ratio is reasonably constant over time, our results indicate that a higher drug concentration may be present in HKLs compared to plasma, and therefore, based on the theoretical assessments by 
Isachsen et al. (2012), therapeutic effects using daily doses of at least 15 and $25 \mathrm{mg} \mathrm{kg}^{-1}$ for flumequine and oxolinic acid, respectively, should be likely. However, when the effect of $5 \mathrm{\mu g} \mathrm{ml}^{-1}$ flumequine on survival and replication activity of Francisella noatunensis subsp. noatunensis within adherent HKLs was analysed by flow cytometry, the results showed no significant difference in the number of infected cells in samples with and without flumequine after 4 and $20 \mathrm{~h}$ (Fig. 5). Since F. noatunensis subsp. noatunensis is slow growing, sampling later than $20 \mathrm{~h}$ could perhaps have revealed a better effect of the drug, but as the flow cytometry analyses showed similar intracellular bacterial replication within leucocytes with and without flumequine, the lack of effect of the drug may have other reasons.

There is a consensus that fluoroquinolones are effective in treatment of various bacterial infections caused by both obligate and facultative intracellular organisms (Carryn et al. 2003). However, Carryn et al. (2002) also observed a decrease in intracellular bactericidal activity especially of ciprofloxacin and to a lesser extent of moxifloxacin against Listeria monocytogenes. The mechanisms are unknown, but comparable results have been observed for other bacteria like Staphylococcus aureus and Chlamydia spp. (Carryn et al. 2003). A similar deactivation may be the reason for the lack of activity of flumequine seen in our study despite a favourable MIC and high intracellular concentration. Our findings that flumequine had no effect on intracellular replication are supported by the findings of Soto et al. $(2010,2013)$, who showed that treatment with florfenicol reduced mortality and prevented lethal disease caused by Francisella noatunensis subsp. orientalis in Nile tilapia Oreochromis niloticus L. but did not eradicate the bacteria. Only a reduction in the number of bacteria in infected HK macrophages using 10 or $100 \mu \mathrm{g}$ florfenicol per $\mathrm{ml}$ of cell culture medium were described. The methods used by Soto et al. $(2010,2013)$ differed from ours, and the intracellular concentrations in macrophages were determined using indirect methods. The advantage of the methods used in the present study is that there is a high accuracy in the measurements and the concentration of drugs and replication of the bacterium are performed directly on the target cells where $F$. noatunensis subsp. noatunensis hide, reside and replicate (Furevik et al. 2011, Vestvik et al. 2013). Such analyses are highly relevant, particularly for bacteria that are not obligate pathogens and where a moderate or transient effect of antibacterial treatment is observed. Flow cytometry allows accurate registrations, and this method is especially valuable when the bacteria are very small and slow growing or may aggregate in suspension.

In this study, we have shown that by applying techniques such as HPLC it is possible to measure the concentration of drugs within isolated cells like leucocytes. By combining such data with pharmacokinetic analyses and the degree of infection of bacteria within cells and intracellular bacterial replication over time using flow cytometry, it may be possible to design future therapy of intracellular bacteria by confirming intracellular efficacy.

Acknowledgements. We thank P. Løvik for valuable technical support.

\section{LITERATURE CITED}

AliAbadi FS, Lees P (2000) Antibiotic treatment for animals: effect on bacterial population and dosage regimen optimisation. Int J Antimicrob Agents 14:307-313

Bakkemo KR, Mikkelsen H, Bordevik M, Torgersen J and others (2011) Intracellular localisation and innate immune responses following Francisella noatunensis infection of Atlantic cod (Gadus morhua) macrophages. Fish Shellfish Immunol 31:993-1004

Birkbeck TH, Feist SW, Verner-Jeffreys DW (2011) Francisella infections in fish and shellfish. J Fish Dis 34:173-187

Burka JF, Hammell KL, Horsberg TE, Johnson GR, Rainnie DJ, Speare DJ (1997) Drugs in salmonid aquaculture - a review. J Vet Pharmacol Ther 20:333-349

Carryn S, Van Bambeke F, Mingeot-Leclercq MP, Tulkens PM (2002) Comparative intracellular (THP-1 macrophage) and extracellular activities of beta-lactams, azithromycin, gentamicin, and fluoroquinolones against Listeria monocytogenes at clinically relevant concentrations. Antimicrob Agents Chemother 46:2095-2103

Carryn S, Chanteux H, Seral C, Mingeot-Leclercq MP, Van Bambeke F, Tulkens PM (2003) Intracellular pharmacodynamics of antibiotics. Infect Dis Clin North Am 17: $615-634$

> Chilmonczyk S, Monge D (1999) Flow cytometry as a tool for assessment of the fish cellular immune response to pathogens. Fish Shellfish Immunol 9:319-333

Fryer JL, Hedrick RP (2003) Piscirickettsia salmonis: a Gram-negative intracellular bacterial pathogen of fish. J Fish Dis 26:251-262

Furevik A, Pettersen EF, Colquhoun D, Wergeland HI (2011) The intracellular lifestyle of Francisella noatunensis in Atlantic cod (Gadus morhua L.) leucocytes. Fish Shellfish Immunol 30:488-494

Gutenberger SK, Duimstra JR, Rohovec JS, Fryer JL (1997) Intracellular survival of Renibacterium salmoninarum in trout mononuclear phagocytes. Dis Aquat Org 28:93-106

> Hansen MK, Horsberg TE (2000) Single-dose pharmacokinetics of flumequine in the eel (Anguilla anguilla) after intravascular, oral and bath administration. J Vet Pharmacol Ther 23:169-174

Isachsen CH, Vågnes Ø, Jakobsen RA, Samuelsen OB (2012) Antimicrobial susceptibility of Francisella noatu- 
nensis subsp. noatunensis strains isolated from Atlantic cod Gadus morhua in Norway. Dis Aquat Org 98:57-62 > Jimenez-Lozano E, Marques I, Barron D, Beltran JL, Barbosa J (2002) Determination of pK(a) values of quinolones from mobility and spectroscopic data obtained by capillary electrophoresis and a diode array detector. Anal Chim Acta 464:37-45

- Li J, Peters R, Lapatra S, Vazzana M, Sunyer JO (2004) Anaphylatoxin-like molecules generated during complement activation induce a dramatic enhancement of particle uptake in rainbow trout phagocytes. Dev Comp Immunol 28:1005-1021

Mikalsen J, Olsen AB, Tengs T, Colquhoun DJ (2007) Francisella philomiragia subsp. noatunensis subsp. nov., isolated from farmed Atlantic cod (Gadus morhua L.). Int J Syst Evol Microbiol 57:1960-1965

Nylund A, Ottem KF, Watanabe K, Karlsbakk E, Krossoy B (2006) Francisella sp. (Family Francisellaceae) causing mortality in Norwegian cod (Gadus morhua) farming. Arch Microbiol 185:383-392

Olsen AB, Mikalsen J, Rode M, Alfjorden A and others (2006) A novel systemic granulomatous inflammatory disease in farmed Atlantic cod, Gadus morhua L., associated with a bacterium belonging to the genus Francisella. J Fish Dis 29:307-311

> Ottem KF, Nylund A, Isaksen TE, Karlsbakk E, Bergh $\varnothing$ (2008) Occurrence of Francisella piscicida in farmed and wild Atlantic cod, Gadus morhua L., in Norway. J Fish Dis 31:525-534

Rønneseth A, Wergeland HI, Pettersen EF (2007) Neutrophils and B-cells in Atlantic cod (Gadus morhua L.). Fish Shellfish Immunol 23:493-503

Rønneseth A, Pettersen EF, Wergeland HI (2012) Flow cytometry assay for intracellular detection of infectious pancreatic necrosis virus (IPNV) in Atlantic salmon (Salmo salar L.) leucocytes. Fish Shellfish Immunol 33:1292-1302

Rønneseth A, Haugland GT, Wergeland HI (2013) Flow cytometry detection of infectious pancreatic necrosis virus (IPNV) within subpopulations of Atlantic salmon (Salmo salar L.) leucocytes after vaccination and during the time course of experimental infection. Fish Shellfish Immunol 34:1294-1305

Samuelsen OB, Bergh $\varnothing$ (2004) Efficacy of orally administered florfenicol and oxolinic acid for the treatment of vibriosis in cod (Gadus morhua). Aquaculture 235:27-35

Samuelsen OB, Hjeltnes B, Torkildsen L (1999) Efficacy of orally administered oxolinic acid and Vetoquinol, an oxolinic acid ester, for the treatment of furunculosis in Atlantic salmon Salmo salar held in seawater. Dis Aquat Org 37:53-59

Editorial responsibility: David Bruno, Aberdeen, UK
Samuelsen OB, Bergh Ø, Ervik A (2003a) Pharmacokinetics of florfenicol in cod Gadus morhua and in vitro antibacterial activity against Vibrio anguillarum. Dis Aquat Org 56:127-133

- Samuelsen OB, Bergh Ø, Ervik A (2003b) A single-dose pharmacokinetic study of oxolinic acid and vetoquinol, an oxolinic acid ester, in cod, Gadus morhua L., held in sea water at $8^{\circ} \mathrm{C}$ and in vitro antibacterial activity of oxolinic acid against Vibrio anguillarum strains isolated from diseased cod. J Fish Dis 26:339-347

Samuelsen OB, Nerland AH, Jørgensen T, Schrøder MB, Svåsand T, Bergh Ø (2006) Viral and bacterial diseases of Atlantic cod Gadus morhua, their prophylaxis and treatment: a review. Dis Aquat Org 71:239-254

> Seljestokken B, Bergh Ø, Melingen GO, Rudra H, Olsen RH, Samuelsen OB (2006) Treating experimentally induced vibriosis (Listonella anguillarum) in cod, Gadus morhua L., with florfenicol. J Fish Dis 29:737-742

Smith P (2008) A cost-benefit analysis of the application of pharmacokinetic/pharmacodynamic-based approaches to setting disc diffusion breakpoints in aquaculture: a case study of oxolinic acid and Aeromonas salmonicida. Aquaculture 284:2-18

Soto E, Endris RG, Hawke JP (2010) In vitro and in vivo efficacy of florfenicol for treatment of Francisella asiatica infection in tilapia. Antimicrob Agents Chemother 54: 4664-4670

> Soto E, Kidd S, Gaunt PS, Endris R (2013) Efficacy of florfenicol for control of mortality associated with Francisella noatunensis subsp. orientalis in Nile tilapia, Oreochromis niloticus (L.). J Fish Dis 36:411-418

- Vestvik N, Rønneseth A, Kalgraff AK, Winther-Larsen HC, Wergeland HI, Haugland GT (2013) Francisella noatunensis subsp. noatunensis replicates within Atlantic cod (Gadus morhua L.) leucocytes and inhibits respiratory burst activity. Fish Shellfish Immunol 35: 725-733

> Vik-Mo FT, Bergh Ø, Samuelsen OB (2005) Efficacy of orally administered flumequine in the treatment of vibriosis caused by Listonella anguillarum in Atlantic cod Gadus morhua. Dis Aquat Org 67:87-92

> Vosbeck K, James PR, Zimmermann W (1984) Antibiotic action on phagocytosed bacteria measured by a new method for determining viable bacteria. Antimicrob Agents Chemother 25:735-741

Zerihun MA, Feist SW, Bucke D, Olsen AB, Tandstad NM, Colquhoun DJ (2011) Francisella noatunensis subsp. noatunensis is the aetiological agent of visceral granulomatosis in wild Atlantic cod Gadus morhua. Dis Aquat Org 95:65-71

Submitted: June 13, 2013; Accepted: November 14, 2013 Proofs received from author(s): January 16, 2014 